\title{
O Estatuto do Corpo em Esquisse D’une Théorie Des Émotions, de Jean-Paul Sartre
}

\author{
Marcelo Galletti Ferretti ${ }^{I}$
}

\begin{abstract}
RESUMO: Neste artigo, pretendo evidenciar algumas dificuldades que cercam a definição do estatuto do corpo em Esquisse d'une théorie des émotions (Esboço de uma teoria das emoçôes), obra de JeanPaul Sartre publicada em 1939. Tais dificuldades, fundamentalmente, advêm do primado que a consciência adquire na eidética sartreana da emoção, o qual acaba por condicionar a atividade do corpo à espontaneidade da consciência. Trata-se, portanto, de uma posição teórica que guarda semelhanças com o intelectualismo, o qual, todavia, é objeto das críticas de Sartre desde o início da referida obra. Com o intuito de assinalar essas questóes, procuro expor a eidética sartreana da emoção, dando ênfase ao estatuto problemático do corpo nela presente. Contudo, é necessário, antes dessa exposição, retomar o teor da censura às teorias psicológicas da emoção no texto de Sartre, em especial a de William James, bem como recuperar algumas teses centrais do próprio James a respeito da emoção.
\end{abstract}

PALAVRAS-CHAVE: Sartre, Jean-Paul. Emoçẫo. Corpo. Consciência. Psicologia. Fenomenologia.

\section{INTRODUÇÁo}

Em Esquisse d'une théorie des émotions (Esboço de uma teoria das emoçóes, doravante Esboço), Jean-Paul Sartre impõe severas censuras tanto às chamadas teorias intelectualistas da emoção - as quais preconizam que um estado anímico causaria as manifestaçôes somáticas verificadas no fenômeno emocional quanto às teorias periféricas - que, ao inverterem a relação de causalidade concebida pelos intelectualistas, afirmam a anterioridade das manifestaçóes somáticas relativamente a seu correspondente anímico. De fato, o filósofo francês endereça suas críticas especialmente às últimas, cujo representante mais distinto é William James (1842-1910). Sartre assinala que o grande problema da concepção de James é purgar da emoção o seu significado e sua finalidade: a emoção não seria desordem fisiológica, como supunha James, mas uma estrutura ordenada destinada a resolver um problema, e, portanto, dotada de sentido. No entanto, Sartre reconhece a importância das manifestaçóes corporais na emoção, conferindo-lhes um papel fundamental: fornecer a ela o

\footnotetext{
${ }^{1}$ Doutorando (FAPESP) em Filosofia pelo Instituto de Filosofia e Ciências Humanas da Universidade Estadual de Campinas (IFCH-Unicamp). E-mail: mgferretti@uol.com.br.
} 
seu caráter de padecimento. Assim, segundo o francês, o corpo seria hylé para a consciência emocionada, a qual, por sua vez, dirigiria o corpo na constituição do mundo mágico da emoção.

Acredito que essa maneira de caracterizar a relação entre consciência e corpo implique uma distinção, na teoria sartreana, entre atividade (da consciência) e passividade (do corpo) que é problemática na medida em que enseja uma interpretação do corpo como algo condicionado à atividade da consciência. Ora, isso acarretaria, em algum grau, um retorno à concepçáo intelectualista, censurada por Sartre logo no início de seu texto. Penso que tal problema, todavia, deve-se a uma dificuldade mais geral, que diz respeito ao estatuto problemático do corpo na teoria sartreana da emoção. Julgo que essa dificuldade se deva a certas exigências internas ao próprio texto de Sartre, às quais darei destaque.

Dessa forma, com o intuito de expor tais problemas, buscarei, grosso modo, em primeiro lugar, retomar brevemente no texto de Sartre os motivos aduzidos para censurar as teorias psicológicas e a teoria psicanalítica da emoção. Em seguida, recuperarei as teses centrais da teoria jamesiana da emoção, procurando elucidar os motivos das críticas e dos elogios de Sartre a ela. Finalmente, procurarei expor a eidética sartreana da emoção, dando ênfase ao estatuto problemático do corpo nela presente.

\section{O RESGATE DO SENTIDO: NATUREZA DA CENSURA SARTREANA ÀS TEORIAS PSICOLÓGICAS SOBRE A EMOÇÁO}

A crítica das diferentes abordagens psicológicas da emoção que vigoravam então desempenha um papel fundamental no Esboço, pois é a partir desse exame que Sartre delineia sua teoria sobre as emoçóes nesse opúsculo publicado em 1939. Com efeito, como indicou Arnaud Tomès (2010, p. CXI), no alentado prefácio que acompanha o opúsculo de Sartre, o Esboço visa a principiar uma cooperação frutífera entre a psicologia e a fenomenologia por meio do "anúncio de um programa filosófico" que será seguido em obras posteriores de Sartre. Daí a advertência deste a respeito da aspiração modesta de seu escrito, a qual não reside em realizar "[...] um estudo fenomenológico da emoção", mas em verificar "[...] se a psicologia pura pode obter um método e ensinamentos da fenomenologia" (SARTRE, 1939/2010, p. 17). Reciprocamente, se o que se pretende é tratar da emoção enquanto algo concreto e vivido, a fenomenologia necessita do aporte dos dados empíricos 
da psicologia, por meio da qual se pode ver "[...] a facticidade da existência humana" (SARTRE, 1939/2010, p. 66, grifos do autor). Assim, nesse texto de Sartre, a psicologia não é mero acessório, mas eixo sobre o qual se ergue a reflexão filosófica.

Embora o opúsculo se abra com uma crítica radical a essa ciência, vêse, à medida que a argumentação sartreana se desenvolve, que não se trata de reprovar a psicologia in toto, mas de conjurar cientificismo que a seduz ${ }^{2}$. $\mathrm{Na}$ verdade, Sartre não apenas endossa certos aspectos atinentes à emoção avançados pela psicologia, conforme veremos, como também os incorpora em sua própria teoria acerca das emoçóes. Desse modo, é necessário ter cautela com a introdução imponente do texto, a qual, ao censurar, de maneira geral, as pretensóes da psicologia de ser positiva, pode nos levar a pensar que o que se anuncia é uma condenação severa dessa ciência. No entanto, como adverte Coorebyter (2004, p. 164), a repreensão de Sartre incide não sobre o que a psicologia faz, mas sobre "[...] o que ela crê dever fazer sob a pressão do cientificismo", de sorte que tal repreensão serve de alerta à influência excessiva e, por conseguinte, prejudicial de princípios cientificistas nessa disciplina.

Antes de evidenciar a dimensão desse prejuízo, o filósofo francês ressalta o encanto que o modelo das ciências naturais exerce sobre a psicologia. Fascinada por esse modelo, a psicologia almeja ser positiva e busca, antes de tudo, os fatos. Porquanto crê que estes correspondem ao que se "[...] deve encontrar ao longo de uma pesquisa” (SARTRE, 1939/2010, p. 8, grifo do autor), à psicologia náo importa saber o que tais fatos significam. Para ela, a pergunta pelo sentido deles náo interessa, da mesma forma que a pergunta pelo sentido da atraçáo entre os corpos segundo a lei de Newton não interessa ao cientista (SARTRE, 1939/2010, p. 16); trata-se de um fato que não significa nada: apenas é. Tal é o tratamento dado pelo psicólogo a seu objeto, o fato psíquico, encarado como um dado natural.

Notamos, por conseguinte, que esse tratamento implica obliterar a dimensão do significado nas pesquisas da psicologia. Elas excluem de seu escopo

\footnotetext{
${ }^{2}$ Chamo de "cientificismo" a atitude de objetivar o fato psíquico. Tal atitude é desde logo identificada por Sartre na psicologia e criticada no decorrer da introdução do Esboço. Assim, o texto abre-se com a enunciação da pretensão da psicologia de ser positiva - isto é, o desejo desta de "[...] extrair seus recursos exclusivamente da experiência" (SARTRE, 1939/2010, p. 1) -, pretensão que, no entanto, revela-se inadequada para se alcançar a essência de um fenômeno psíquico como a emoção, conforme veremos. De todo modo, tomo como cerne do cientificismo em psicologia essa pretensão insidiosa do psicólogo de, como diz Sartre, estar "[...] diante de seu objeto assim como o físico está diante do dele" (Idem, ibid.).
} 
a subjetividade, uma vez que, emulando o estilo de objetividade das ciências naturais, desejam encarar o fato psíquico como um dado natural. Essa exclusão leva à exclusão da dimensão do significado, já que é apanágio da subjetividade conferir sentido ao fato psíquico. É apenas por intermédio do sujeito que se encontra o sentido desse fato: sem o recurso ao sujeito, o pavor diante de uma figura assustadora, por exemplo, reduz-se a alteraçóes somáticas verificáveis, como sudorese, dilatação das pupilas e dos vasos sanguíneos - no entanto, o pavor não equivale a tais alteraçóes, como mostrarei mais abaixo. Sartre sistematiza essa não-equivalência, ao salientar que o sentido não é uma "[...] qualidade colocada de fora" , mas algo que somente existe na medida "[...] em que é 'assumido' pela realidade humana [...]” (SARTRE, 1939/2010, p. 18). Vê-se, pois, por que o psicólogo considera "[...] o estado psíquico de modo a lhe retirar toda significação” (SARTRE, 1939/2010, p. 16, grifo do autor).

Ora, o prejuízo mais grave dessa atitude do psicólogo é a incapacidade de compreender a essência mesma de seu objeto, o psíquico. Se o ato de significar é inerente à subjetividade e, portanto, ao ser humano, o que distingue o psíquico dos fatos encontrados na natureza é que aquele possui um sentido; isto é, o sentido é condição de existência do psíquico. Consequentemente, retirar-lhe sua significação, conclui o autor, é retirar-lhe "[...] sua natureza de fato humano" (SARTRE, 1939/2010, p. 16). Como evidenciou Moutinho (1995), ao comentar brevemente as feiçôes do Esboço, o que permite a Sartre tomar o sentido como essência do psíquico é, na verdade, um duplo movimento: em primeiro lugar, trata-se de dar o estatuto de fenômeno da consciência ao psíquico, via régia que possibilitará, em seguida, alcançar sua essência, o sentido. Assim, "[...] estudar o psíquico como fenômeno e, por conseguinte, como significante" (MOUTINHO, 1995, p. 101) corresponde à rota que o psicólogo náo pode perder de vista na busca por seu objeto de investigação, sob pena de nunca alcançar a essência deste.

Por isso, trata-se de um imperativo, para Sartre, resgatar o sentido de um fenômeno da consciência como o da emoção. Buscar o sentido da emoção significa buscar a relaçáo singular que se estabelece entre o sujeito e o mundo. Embora, como frisei, essa questáo seja explorada mais abaixo, basta indicar, por ora, que buscar esse sentido é perscrutar aquilo que vai além das alteraçóes somáticas verificáveis na emoção. Retomando o exemplo fornecido acima, se o pavor diante da figura assustadora me leva ao desmaio, essa atitude náo deve ser encarada como mera consequência de mecanismos fisiológicos, mas como uma forma, adotada por mim, de evitar a situação apavorante. Como 
esclarece Sartre (1939/2010, p. 45), “[...] na impossibilidade de poder evitar o perigo pelas vias normais e pelos encadeamentos deterministas, eu o neguei”. Sartre insiste que é na finalidade de uma atitude como essa que reside o seu verdadeiro sentido e, por conseguinte, sua essência. Daí o fato de o autor afirmar sinteticamente que a emoção "[...] é na estrita medida em que ela significa" (SARTRE, 1939/2010, p. 16, grifo do autor).

Sartre deseja inculcar esse imperativo do sentido nas pesquisas da psicologia, sobretudo nas que ignoram tal imperativo deliberadamente. $\mathrm{Na}$ verdade, o autor reconhece que certas psicologias - a de Pierre Janet (18691957), a psicologia da Gestalt e a psicanálise - atentaram, em graus diferentes, para tal questão e merecem ser retomadas por isso - o que indica que, como mostrou Foucault (1999), conquanto a preocupação em alinhar-se com as ciências da natureza tenha marcado, de forma indelével, o projeto da psicologia e possibilitado o próprio surgimento dessa ciência enquanto disciplina autônoma, no final do século XIX, o interesse em abordar a dimensão do significado já aparecia, ainda que timidamente, desde essa mesma época, em certas pesquisas. Não obstante esse interesse tenha conseguido penetrar na psicologia, ele se tornou central somente em investigaçôes como as da fenomenologia husserliana, que "[...] fez da descrição rigorosa do vivido projeto de toda filosofia tida como ciência” (FOUCAULT, 1999, p. 129). Daí os limites, para Sartre, das pesquisas psicológicas e a necessidade de um novo aporte - o da fenomenologia - para salientar a centralidade da dimensão do sentido.

A partir desse aporte, Sartre, derivando mais prejuízos da atitude naturalista do psicólogo, pode atestar que as pesquisas da psicologia as quais visam unicamente aos fatos estâo condenadas a uma perpétua desordem. Como se viu, essas pesquisas não se interessam pelo sentido dos fatos obtidos ao longo da investigação e preterem juízos e conceitos mais rigorosos a respeito de tais fatos, na esperança de que estes possam, a posteriori, configurar uma unidade. Ocorre que, para o filósofo francês, essa unidade nunca poderia ser atingida. Náo se pode alcançá-la se o que se busca, em primeiro lugar, é uma exaustiva coleção de dados a respeito do objeto investigado, e não a compreensão de sua essência. Inspirando-se declaradamente nas reflexóes husserlianas que revelam uma "[...] incomensurabilidade entre as essências e os fatos", o autor afirma que somente aquelas permitem classificar e inspecionar estes ((SARTRE, 1939/2010, p. 12). Dessa maneira, esse desinteresse pelo sentido, essência dos fatos psicológicos, resulta, para Sartre, no conjunto desarmônico e profundamente heterogêneo de dados a que se assiste, na 
psicologia. A despeito dos esforços dessa ciência, o autor constata que é impossível, de jure, tornar esse conjunto harmônico, porquanto "[...] esperar o fato é, por definição, esperar o isolado, é preferir, por positivismo, o acidente ao essencial, o contingente ao necessário, a desordem a ordem; é abandonar, por princípio, o essencial ao devir [...]" (SARTRE, 1939/2010, p. 9, grifo do autor). Destarte, se as pesquisas psicológicas não visam desde o início às essências de seus objetos de estudo, não podem esperar enxergá-los de forma ordenada - numa palavra, não podem compreendê-los.

Daí o fracasso das teorias psicológicas que realizam um estudo coartado da emoção - isto é, que buscam "[...] a explicação ou as leis da emoção não nas estruturas gerais e essenciais da realidade humana, mas, ao contrário, nos processos da própria emoção [...]" (SARTRE, 1939/2010, p. 12). Esta é concebida por tais teorias como um aglomerado de fatores complexos (manifestações somáticas, comportamentos, estados anímicos) que deve ser examinado separadamente e de cuja análise se espera obter explicaçôes ou leis que os ordenem: é assim que a emoção se torna "[...] objeto de um capítulo após outros capítulos, como o cálcio, nos tratados de química, depois do hidrogênio e do enxofre" (SARTRE, 1939/2010, p. 11). À luz do exposto, podemos ver que esse modo de proceder é malsucedido não apenas devido à impossibilidade de atingir essa ordenação como também porque, de fato, um exame que decompóe a emoção a despe de seu sentido e, por conseguinte, de seu caráter humano: pois, "[...] se realmente todo o fato humano é significante, a emoção é, por natureza, morta para o psicólogo, não-psíquica, inumana" (SARTRE, 1939/2010, p. 16). Portanto, um estudo coartado da emoção está condenado a fracassar tanto de direito como de fato, passando ao largo da essência do fenômeno emocional.

É por esse motivo que Sartre rechaça, de forma geral, tanto as chamadas teorias intelectualistas quanto as periféricas. Enquanto as primeiras "[...] estabelecem uma sucessão constante e irreversível entre o estado íntimo encarado como antecedente e os distúrbios fisiológicos encarados como conseqüentes" (SARTRE, 1939/2010, p. 11), as últimas alteram a ordem de sucessão desses acontecimentos e julgam que tais distúrbios antecedem o estado mental. Para Sartre, porém, a maneira como essa ordem é concebida não impede que a própria emoção seja tratada como um fato em ambas as teorias. Elas não inquirem o significado da conduta emocional, nem verificam a relação que esta estabelece entre o sujeito e o mundo que o rodeia. 
Ao rechaçar essas teorias, Sartre, com efeito, mostra-se determinado a superar a dicotomia em que se assentava o estudo da emoção. Na França, essa dicotomia era propalada por grandes expoentes da tradição da psicologia francesa, como Théodule Ribot (1839-1916), um dos nomes mais importantes dessa tradição, e Georges Dumas (1866-1946), discípulo devotado de Ribot, figura eminente na difusão e institucionalização da psicologia e organizador do primeiro tratado da área, no país (CARROY et al., 2006, p. 136): o Traité de Psychologie - o qual, segundo Patrick Vauday (2004, p. 145), contribuiu decisivamente para a constituição da cultura psicológica do jovem Sartre ${ }^{3}$. Dumas (1923, v. 1, 671-686; 1932, v. 2, p. 432-440) e, sobretudo, Ribot (1896, p. VIII) inscreveram o embate entre teorias intelectualistas e periféricas ou fisiológicas na literatura psicológica da época - embate que acabou se tornando extremamente influente, como atestou Lalande (1975, p. 524). Conforme procurei evidenciar, Sartre busca ir além dessa dicotomia - ou melhor, aquém, porquanto revela que a base dessas teorias, isto é, a própria concepção de emoção, é problemática .

Além disso, o filósofo francês também se mostra disposto a afastar da investigação da emoção o mecanicismo, traço que, da mesma forma, era bastante presente nessa tradição francesa. Autores como Ribot e Dumas, bem como Pierre Janet, um dos discípulos mais célebres de Ribot e um dos autores mais conhecidos da psicologia francesa, detiveram-se no tema da emoção, examinando-a (no caso de Ribot e Janet) sob uma ótica evolucionista (CARROY et al., 2006, p. 62, 133), quando não francamente organicista (no caso de Dumas), com o privilégio da "[...] organogênese em detrimento da

\footnotetext{
3 Segundo Carroy et al. (2006, p. 137), esses tratados abrigavam uma miríade de posições teóricas: "O que caracteriza esses dois tratados [...] é a sua extraordinária heterogeneidade. Eles não apresentam qualquer unidade, teórica ou metodológica, e os desacordos entre os autores são muito mais numerosos do que os seus pontos de convergência [...] Longe de apresentar uma síntese entre as conquistas e a disciplina e de denotar sua unidade, esses tratados póem em evidência sua divisáo [éclatement] e seus conflitos atuais ou pontuais". De posse dessa avaliação, não seria insensato pensar que os próprios tratados de Dumas possam ter dado provas ao jovem Sartre da desordem, bradada no opúsculo sartreano em questáo, que imperava na psicologia - em cujas obras, para o autor, assistia-se à junção de assuntos tão heterogêneos como a ilusão estroboscópica e o complexo de inferioridade (SARTRE, 1939/2010, p. 9).

4 Ainda que os nomes de Ribot e Dumas não sejam mencionados no Esboço, Sartre os citará em L'Imaginaire ( $O$ imaginário), declarando que a psicologia francesa permaneceu presa, no que tange à questão da afetividade, às formulaçôes de Ribot, expressas em Psychologie des sentiments (SARTRE, $1940 / 1986$, p. 135) - donde o tratado de Dumas ainda promover discussōes, velhas e fastidiosas para Sartre, sobre as teorias periféricas e as teorias intelectualistas sobre a emoçáo (ibid., p. 135). Dessa forma, essas breves mençôes a Ribot e Dumas comprovam o rechaço de Sartre à maneira como a psicologia francesa tradicionalmente vinha abordando o tema das emoções.
} 
psicogênese [...]" (p. 136). Embora Sartre (1939/2010, p. 23-28) valorize certas reflexôes da obra tardia de Janet sobre o tema, amparadas sobre a noção de conduta de fracasso, as investigaçôes desses autores da psicologia francesa, de maneira geral, eram orientadas por uma perspectiva naturalista em princípio - ou mecanicista, nos termos de Sartre. Visto que a relaçáo entre o eu e o mundo é totalmente secundária nessa perspectiva, pode-se entender o intento sartreano de distanciar-se dela.

As críticas de Sartre a esse tipo de orientação gravitam, todavia, nomeadamente, sobre um autor do ultramar: William James. É esse autor, para Sartre, o representante da teoria fisiológica ou periférica, como veremos a seguir. De todo modo, é importante reter da exposição realizada até aqui o fundamento do juízo de Sartre a respeito dos estudos da emoção. O filósofo francês assesta suas críticas contra os princípios das teorias que passam ao largo do significado da conduta emocional: tal é o teor da censura de Sartre às teorias psicológicas sobre a emoção.

\section{A teoria de JAMES E O PAPEl do CORPo E DA CONSCIÊNCIA NA EMOÇÃo}

Apesar de ser propriamente examinada apenas no primeiro capítulo do Esboço (dedicado à retomada crítica de algumas "teorias clássicas" da emoção), a teoria de William James é objeto privilegiado das críticas de Sartre desde o início do texto, pois ela se pauta por uma visão mecanicista exemplar da emoção. À medida que Sartre salienta a importância da dimensão do significado e da finalidade no fenômeno emocional, percebe-se que enfocar unicamente as reaçôes somáticas da emoção é bastante insuficiente. Donde Sartre (1939/2010, p. 16) fazer questão de deixar claro que ele, de início, não se perderá “[...] no estudo dos fatos fisiológicos porque, precisamente, tomados em si mesmos e isoladamente, eles não significam quase nada: eles são, eis tudo". Vê-se, por conseguinte, que essa procura pelo significado torna "[...] impossível considerar a emoção como uma desordem psicofisiológica" (SARTRE, 1939/2010, p. 17) como querem, para o filósofo, os adeptos da teoria jamesiana. Em consequência, por ser, para Sartre, o epítome do mecanicismo no estudo da emoção, essa teoria é escolhida pelo filósofo francês para figurar no centro de seu horizonte crítico desde o momento em que é fundamentada a necessidade de resgatar o sentido da emoção ${ }^{5}$.

5 Deve-se ressalvar que, na verdade, de acordo com Richards (1989, p. 436-440), James admitia um sentido nos comportamentos emocionais, ainda que segundo os moldes evolutivos darwinianos. Não 
Deve-se ressaltar que não se trata, contudo, de uma escolha abritrária por parte de Sartre. Segundo Dixon (2006, p. 211), a teoria de James tornouse a "[...] mais citada e o ponto de partida, virtualmente, de toda a discussão acadêmica sobre a emoção desde o início dos anos 1890 em diante, e talvez até os dias atuais". Por esses motivos, a passagem pela teoria jamesiana é obrigatória numa reflexão sobre as abordagens da psicologia sobre o tema da emoção. Ademais, a publicação dos escritos de James referentes a esse tema, ainda de acordo com Dixon (2006, p. 212), coincidiu com a institucionalização da psicologia na América e na Europa, onde foram criados departamentos em universidades e revistas de psicologia, o que indica que tais escritos inauguraram a profissionalização dos estudos da ciência psicológica a respeito da emoção ${ }^{6}$. Se Sartre visa a conjurar o cientificismo sedutor na psicologia, como indiquei acima, nada mais apurado que se dirigir a esse momento inaugural das investigaçôes da psicologia positiva nascente, encetadas por James. Por esses motivos, o destaque dado à teoria deste é bastante pertinente e justificado.

Embora essa escolha denote conhecimento da teoria jamesiana, bem como de sua importância, por parte de Sartre, este não pretende esquadrinhar tal teoria, mas extrair desta apenas a tese básica: a emoção é resultado das manifestaçôes somáticas. Por conseguinte, o designativo "fisiológica" aplicado a essa teoria objetiva salientar que o conjunto de alteraçóes somáticas era causa da emoção para James. Já o qualificativo "periférica” alude ao privilégio dado pelo norte-americano à atividade visceral, em lugar da cerebral ou mesmo anímica, na causação da emoção. De toda forma, o essencial da tese de James, para Sartre, "[...] é que o estado de consciência dito 'alegria, cólera, etc.' não é senão a consciência das manifestaçóes fisiológicas - a projeção destas na consciência, se quisermos" (SARTRE, 1939/2010, p. 22, grifo do autor). O filósofo francês busca precisamente frisar o fato de a emoção, para James, ser a consciência das reações corporais.

obstante, a crítica clara de Sartre (1939/2010, p. 33), conquanto muito breve, à "emoção-instinto" indica que este rejeita a acepçáo evolutiva da noçáo de "sentido".

${ }^{6}$ Dixon enfoca esse processo (bem como, em geral, o processo de apropriação do tema da emoção pela ciência) com um viés bastante crítico - por exemplo, "[...] a teoria reducionista de James sobre a emoção é um monumento obsoleto, senão falho, à nova profissão da psicologia pela qual James lutou com sucesso. Essa teoria foi mais um símbolo de mudança cultural e intelectual do que um bom modo de dar conta daqueles estados mentais que as pessoas chamavam de emoçôes” (DIXON, 2006, p. 212). Não me interessam, no presente artigo, os juízos emitidos por Dixon (2006) sobre a teoria de James, mas apenas o relato do impacto dessa teoria sobre os estudos da emoção. 
De fato, é o que afirma o próprio James, ao sublinhar que sua teoria é produto da inversão do modo como a emoção é concebida tradicionalmente:

\begin{abstract}
Nossa maneira natural de conceber essas emoçóes brutas [coarser emotions] é que a percepção de algum fator excita a afecção mental chamada emoção, e que este estado origina a expressão corporal. Minha teoria, ao contrário, concebe que as mudanças corporais sucedem diretamente a percepção do fator excitante, e que nossa sensação dessas mudanças É a emoção. (JAMES, 1890/1983, p. 1065, grifos do autor).
\end{abstract}

O excerto evidencia o componente reflexo da emoção, eliciada "diretamente" pelos impulsos nervosos oriundos da estimulaçáo perceptiva - sem qualquer comando cerebral ou anímico, como quer a concepção tradicional ou "natural". James inverte completamente a teoria intelectualista, anunciando que a emoção é função dos distúrbios fisiológicos. Com efeito, ao promover essa inversão, o psicólogo norte-americano, como apontou Dixon (2006, p. 210), faz mais do que apenas condicionar as emoçóes a esses distúrbios, pois estas, segundo James (1890/1983, p. 1068, grifos meus), "[...] são, a bem da verdade, constituidas e elaboradas por aquelas alteraçóes corporais as quais comumente chamamos sua expressão ou consequência". Destarte, a inversão promovida por James faz do que se costuma chamar de aspectos expressivos da emoção a verdadeira causa desta.

Contudo, o que confere a ela caráter genuíno não são expressôes corporais quaisquer, mas as mudanças de natureza fisiológica. São elas as responsáveis pela verdade e unicidade da emoção. James (1890/1983, p. 1066) afirma que a infinidade de reaçóes orgânicas sofridas pelo sujeito emocionado é o que torna táo difícil reproduzi-las voluntariamente, após a reação emocional. Ainda que seja possível refazer movimentos voluntários, é impossível controlar reações viscerais como a das glândulas, do coração e do diafragma. Daí a centralidade da metáfora jamesiana da "caixa de ressonância" (JAMES, 1890/1983, p. 1066, grifos do autor) para o corpo emocionado: excitado, esse corpo como que produz uma série frequências próprias de vibração que são sentidas pelo cérebro, o qual, por sua vez, concede a elas, posteriormente, a qualidade do sentimento. Além de ilustrar muito bem a primazia da excitação somática na causação da emoçáo e a excitabilidade do corpo emocionado, essa metáfora capta, de maneira notável, a espontaneidade do corpo, o qual gera uma vastidão de espectros emocionais, tão múltiplos 
quanto podem ser as combinaçôes de açôes viscerais. É essa plêiade de reaçôes fisiológicas que determina a especificidade da emoção ${ }^{7}$.

É por isso que esta é distinta da percepção, do instinto e do julgamento, faculdades que possuem ligação íntima com a emoção sem, no entanto, confundir-se com ela. Desse modo, ela não é nem puro ato cognitivo, nem a mera reação prática a um estímulo, nem a decisão de fuga após a avaliação de uma ameaça, por exemplo. O que caracteriza a emoção, para o psicólogo norteamericano, é o fato de "[...] que cada uma das alteraçôes corporais, quaisquer que sejam, é SENTIDA, distinta ou obscuramente, no momento em que ocorre" (JAMES, 1890/1983, p. 1068, grifos do autor). Facilmente detectáveis ou não pelo sujeito emocionado, a série de reaçóes orgânicas o mobilizam, tomam-no, ocupam-no; é disso que ele se dá conta, e é esse o traço distintivo da emoção. Logo, a abstração dessas alteraçôes implica que "[...] não encontremos nada por trás, nenhuma 'matéria-mental' da qual a emoção possa ser constituída, e que um estado frio e neutro de uma percepção intelectual é tudo o que reste" (JAMES, 1890/1983, p. 1067). Tal é o "ponto vital" (JAMES, 1890/1983, p. 1067) da teoria de James, que arrola vários exemplos, tanto da normalidade quanto da patologia, os quais revelam que a emoção não é puro ato intelectivo ou mero móvel para a ação, mas, sim, a sensação (feeling) de manifestaçóes corporais (JAMES, 1890/1983, p. 1074).

Com isso, essa teoria destaca uma das características mais fundamentais da emoção: o padecimento. O sujeito emocionado não experimenta abstraçóes desencarnadas, mas sensaçóes físicas concretas - fenômeno que expressóes da linguagem comum, como "sentir na pele", captam tão bem. O corpo desse sujeito apresenta uma série de modificaçóes orgânicas que rompem o "silêncio dos órgãos"; como na doença, ele se torna consciente de seu próprio corpo; e como se estivesse em meio a uma violenta intempérie, não consegue deter

\footnotetext{
${ }^{7}$ Isso também escuda a rejeição de James das descriçôes e classificaçôes das emoçôes - atitudes que, segundo o autor, representavam o estágio mais baixo da ciência (JAMES, 1890/1983, p. 1069): "Após termos dado conta da gênese de uma emoção [...] imediatamente vemos por que o número de emoçóes possiveis é ilimitado e por que as emoçôes de diferentes individuos variam indefinidamente [...]" (ibid., p. 1069, grifos do autor). Ao que parece, nesse ponto reside mais uma divergência entre James e Sartre, já que, para este, o trabalho de classificação seria útil e fecundo, contanto que isso estivesse condicionado à compreensão da estrutura funcional da emoçáo (SARTRE, 1939/2010, p. 50). Ademais, como se pode atestar em várias passagens do opúsculo, a descriçáo dos fenômenos é de suma importância para o filósofo francês.

${ }^{8}$ Faço livre uso da afirmação do cirurgiáo René Leriche (1879-1955), para quem “[...] a saúde é a vida no silêncio dos órgãos" (LERICHE apud CANGUILHEM, 1978, p. 67).
} 
a progressão do acontecimento nem evitá-lo ${ }^{9}$. Assim, para James, a emoção é uma experiência de padecimento que captura o sujeito.

Quanto a essa questão, James e Sartre estão em perfeito acordo. De fato, como sublinhou Baugh (1990, p. 357), “[...] a teoria de Sartre é mais próxima da de James do que geralmente se reconhece [...]", e essa proximidade reside justamente na importância dada pelos dois filósofos ao corpo na emoção. Para ambos os autores, a emoção instaura uma realidade que cativa o sujeito de tal forma que ele não consegue, por seu arbítrio, evadir-se a ela. O sujeito não escolhe, por meio de um ato reflexivo, emocionar-se; não há qualquer ação intelectiva que anteceda esse ato e possa freá-lo: como enfatiza Sartre (1939/2010, p. 38, grifos meus), a emoção "[...] nos invade apesar de nós". O que dá esse caráter real e inevitável à emoção são exatamente as sensaçóes físicas e modificaçóes orgânicas que sofre o sujeito, as quais fazem dela fenômeno encarnado, padecido e verdadeiro. Isso, com efeito, toca a essência do fenômeno emocional para Sartre, e é sondado num dos momentos eidéticos fundamentais da teoria sartreana, como veremos. Por isso, bastante ciente da importância de considerar esses aspectos basais explicitados por James, Sartre os incorpora em sua própria teoria.

A grande dificuldade de incorporação da teoria periférica in toto, não obstante, advém, segundo o filósofo francês, do traço de projeção que as emoçôes ainda guardam relativamente à consciência. Para James, esta é simples epifenômeno ${ }^{10}$, reflexo da espontaneidade do corpo. Ora, isso traz ao menos dois grandes problemas aos olhos de Sartre. Em primeiro lugar, não se explica, para ele, como essa espontaneidade aparece à consciência de modo intensamente penoso. Mesmo uma descrição completa das reaçóes somáticas de um sujeito em estado de pavor, por exemplo, não pode dar conta da dimensão vivida por esse sujeito. Tomès (2010, p. XLIII) captou essa dimensão: trata-se de um estado no qual "[...] o instinto vital parece paralisado", de um estado "de aniquilamento do ser". Vê-se que o recurso à espontaneidade somática não é de forma alguma suficiente para caracterizar a dimensão propriamente

\footnotetext{
${ }^{9}$ A comparação inspira-se nas palavras do próprio James (1890/1983, p. 1068, grifos meus): "Seria talvez demasiado esperar que ele [o sujeito emocionado] freasse o fluxo intenso da erupção passional [to arrest the tide of any strong gust of passion] [...]".

${ }^{10}$ Ao equiparar emoçóes a sensaçôes físicas de prazer e dor, o próprio James (1890/1983, p. 1082, grifos meus) dá mostras do caráter projetivo da consciência: "Se nossa hipótese é correta, entâo percebemos, mais claramente do que nunca, que nossa vida mental é ligada [knit up], no sentido estrito do termo, à nossa compleiçáo corporal [corporal frame]. Arrebatamento, amor, ambição, indignação e orgulho, na qualidade sentimentos [feelings], são frutos do mesmo solo do qual brotam o prazer e a dor".
} 
existencial desse estado penoso. Eis o motivo pelo qual Sartre (1939/2010, p. 22) qualifica de "inconcebível" o fato de um estado corporal, por si só, aparecer à consciência com esse caráter penoso. Em segundo lugar, não se atenta, de acordo com o filósofo francês, para a diferença enorme que há entre as reaçôes somáticas e a emoção. Enquanto as primeiras, em si mesmas, são caóticas, a emoção é dotada de sentido e decorre da ligação que o sujeito estabelece com o mundo. Ora, essa ligação, contesta o autor, não é caótica: “[...] é uma estrutura organizada e discernível" (SARTRE, 1939/2010, p. 22, grifo meu $)^{11}$. Tais são os problemas mais sérios de uma teoria que considera a consciência uma projeção da atividade somática.

Dessa forma, pode-se destacar que as objeçóes de Sartre a respeito da teoria jamesiana incidem justamente sobre a espontaneidade do corpo, na medida em que ela, tomada em si mesma, sem qualquer referência à consciência, é incapaz de explicar o sentido do fenômeno emotivo. O corpo, para o filósofo francês, não pode "[...] conferir sentido a suas manifestaçôes" (SARTRE, 1939/2010, p. 18, grifos meus), tese importantíssima anunciada ainda na introdução do opúsculo. É essa tese que leva o autor a afirmar que “[...] a emoçáo não existe enquanto fenômeno corporal, pois um corpo não pode ser emocionado [...]" (SARTRE, 1939/2010, p. 18). Veremos que Sartre define a emoção como uma forma sintética composta pelas reaçóes somáticas e a conduta, meio pelo qual se descobre o sentido e a finalidade da emoção - donde ele declarar, quase ao final de seu escrito, que "[...] o erro da teoria periférica é precisamente tê-los [os fenômenos fisiológicos] considerado isoladamente" (SARTRE, 1939/2010, p. 52). Se o corpo não é capaz de dotar de sentido suas reaçóes, então essa tarefa deve-se à consciência. De fato, segundo o autor, "[...] só ela pode dar conta da finalidade da emoção" (SARTRE, 1939/2010, p. 32), o que indica que a consciência desempenha uma função importante na relação com o corpo - função que a teoria de James, no entanto, parece não contemplar.

$\mathrm{Na}$ verdade, após acompanhar a argumentação de Sartre no decorrer de todo o primeiro capítulo do Esboço, notamos que, mais que uma função importante, a consciência desempenha um papel absolutamente fundamental. Afinal, se apenas ela pode explicar o sentido da emoção - justamente o que as teorias psicológicas não conseguiram fazer satisfatoriamente -, conclui-se que

${ }^{11}$ Essa palavra "estrutura" é extremamente importante, como assinalou Tomes (2010, p. XLIII), pois ela já anuncia que, para Sartre, a emoção é um conjunto sintético de diferentes elementos unidos por um sentido - questăo que é desenvolvida na eidética da emoção. 
devemos nos voltar para ela, a fim de obtermos uma compreensão adequada do fenômeno emotivo. Tal é o resultado a que chega Sartre (1939/2010, p. 32, grifo meu), ao término do capítulo: não é possível compreender a transformação emocional "[...] sem admitir primeiro a consciência"; apenas ela, diz o filósofo, pode, “[...] por sua atividade sintética”, conduzir essa transformação. Vê-se, afinal, que o autor parte da teoria jamesiana para (após examinar as teorias de Janet e da psicologia da Gestalt) retornar, "[...] enfim, à consciência” (SARTRE, 1939/2010, p. 32): esta é o verdadeiro telos de Sartre.

Nesse momento, entendemos por que a busca pelo sentido conduz o filósofo francês à abordagem fenomenológica. Com efeito, o autor já havia indicado, no início do texto, a centralidade da interrogação da consciência para o fenomenólogo (SARTRE, 1939/2010, p. 15), mas essa indicação adquire pleno sentido somente após a detecção do epifenomenismo que norteia a teoria de James e de outros autores clássicos, envoltos num mecanicismo que teve eco em diversas teorias psicológicas da emoção. O posicionamento crítico adotado por Sartre relativamente a essas teorias clássicas serve de propedêutica e, como afirmou Tomès (2010, p. LXXIII), desempenha o papel essencial de permitir “[...] compreender que o que estava em jogo numa teoria da emoção era o estatuto da consciência".

Isso ainda vale para a breve abordagem sartreana da teoria psicanalítica no capítulo seguinte, dado que Sartre procura evidenciar em tal capítulo que para a psicanálise, igualmente, a consciência é reflexo: não da atividade somática, mas do inconsciente. Ao demonstrar que o psicanalista segue a regra de remontar aos motivos inconscientes a partir dos vestígios veiculados através da consciência, o autor denuncia o estatuto passivo e secundário desta, reduzida a coisa, na teoria psicanalítica. Com isso, essa teoria acaba por rejeitar o cogito cartesiano e instaurar uma cisão entre o significado e o significante, entre um fato e seus efeitos. Visto que a consciência não é coisa, mas "[...] ao contrário, é a condição de existência de todas as coisas, no sentido que ela lhes desvela ou lhes revela” (TOMĖS, 2010, p. LXVII), ela não deve nunca estar alijada da significação. Daí por que Sartre (1939/2010, p. 36, grifos do autor) afirma que "[...] a consciência, se o cogito é possível [e Sartre não duvida disso], é ela mesma o fato, a significação e o significado". Assim, é na consciência que se deve buscar a significação, e não no inconsciente. Ainda que o filósofo reconheça que a psicanálise tenha sido "[...] certamente a primeira a acentuar a significação dos fatos psíquicos" (SARTRE, 1939/2010, p. 34) - ou seja, a "[...] insistir no fato de que todo o estado de consciência vale por outra 
coisa que não ele próprio" (SARTRE, 1939/2010, p. 34, grifos meus), preceito abraçado por Sartre não apenas no opúsculo em questão como também em sua grande obra, L'Etre e le néant (O Ser e o nada), como indica Tomès (2010, p. LXIII) -, a forma como a teoria psicanalítica concebe a consciência é tão problemática quanto a verificada nas teorias clássicas da emoção.

Torna-se oportuna, por conseguinte, a intervenção do saber fenomenológico, erigido sobre uma investigação rigorosa da consciência. Ao realizar a crítica das teorias psicológicas e da abordagem psicanalítica da emoção, Sartre reforça a necessidade da caução do primado da consciência, e pavimenta o caminho para uma eidética da emoção. Antes disso, entretanto, resta ainda afastar de vez alguns equívocos sobre a natureza da consciência que opera na emoção, como veremos. De qualquer forma, já é possível, após o que foi exposto até o momento, enxergar mais nitidamente os desafios que Sartre impóe a si mesmo ao tentar elaborar uma teoria da emoção que busque superar a referida dicotomia entre a posição intelectualista e a posição periférica. Nesse sentido, por um lado, o autor deve mostrar a importância da tarefa significante da consciência sem descambar para o intelectualismo e, por outro, deve contemplar a função capital do corpo sem tomar a consciência como mera projeção da espontaneidade corporal: empreitada hercúlea sem dúvida, sobretudo considerando-se que Sartre procura realizá-la nas poucas páginas que restam ${ }^{12}$ - e, o que é mais arriscado, levando-se em conta que a solução do autor já acena privilegiar o esclarecimento do estatuto da consciência no fenômeno emotivo.

\section{A EidÉTICA SARTREANa dA EMOÇão E O FANTASMa do INTELECTUALISMO}

Conforme já indiquei logo acima, Sartre, antes de esboçar sua teoria, procura dissipar uma confusão - como vimos, presente na maioria das teorias psicológicas e mesmo na psicanálise, de acordo com o autor - relativa à natureza da consciência. Mais especificamente, essa confusão consiste em pressupor que a consciência da emoção é primeiramente reflexiva, ou seja, que é sempre necessária a intermediação de uma atitude reflexiva entre a reação emocional e o mundo. De fato, o autor já havia anunciado, em um texto anterior, $\mathrm{La}$

\footnotetext{
${ }^{12}$ Bem entendido, nas poucas páginas que restam do opúsculo tal como foi publicado pelo autor - e não nas páginas que supostamente deveriam ser publicadas sob o título de La Psyché. Como se sabe, Sartre, partir de 1937, teria começado a escrever uma obra de fôlego, que portaria o referido título, a qual conteria as principais linhas de sua filosofia. Dessa obra, que teria sido perdida em sua maioria, teria restado apenas uma ínfima parte: a que corresponde ao Esboço tal como o conhecemos.
} 
transcendance de l'ego: esquisse d'une description phénomenologique ( $A$ transcendência do ego: esboço de uma descrição fenomenológica), que os psicólogos frequentemente confundem "[...] a estrutura essencial dos atos reflexivos com aquela dos atos irrefletidos" (SARTRE, 1937/1966, p. 39). Uma das grandes novidades desse texto, aliás, foi provar que o eu apenas surge no plano refletido, de modo que "a consciência irrefletida deve ser considerada como autônoma” (SARTRE, 1937/1966, p. 41). No entanto, o filósofo, no opúsculo sobre as emoçóes, dispensa a necessidade de retomar toda essa teoria da consciência desenvolvida anteriormente, ao julgar que, mesmo sem ela, é possível compreender claramente que "[...] a consciência emocional é, em primeiro lugar, consciência do mundo” (SARTRE, 1939/2010, p. 38, grifo do autor). Realmente, basta considerar, como indica o autor, que "[...] a emoção retorna a todo o instante ao objeto e dele se alimenta" (SARTRE, 1939/2010, p. 39), para suspeitar que haja uma íntima união entre a emoção e o mundo. Se temos pavor, temos pavor de alguma coisa; se temos raiva, temos raiva de alguém. Essa elucidação é ocasião para a anunciação da tese central sartreana a respeito do fenômeno emotivo: “[...] a emoção é uma certa maneira de apreender o mundo" (SARTRE, 1939/2010, p. 39), tese calcada sobre o caráter intencional da consciência operante no fenômeno emotivo.

Todavia, a confusão a respeito da natureza dessa consciência ainda não foi de todo dissipada, de sorte que se faz necessário percorrer a essência da conduta irrefletida. Trata-se, portanto, do primeiro momento eidético do texto $^{13}$, passo fundamental para a compreensão da teoria sartreana da emoção. Mais precisamente, Sartre promove uma descrição fenomenológica da ação nesse momento. Por meio de um exemplo central - o ato de escrever, sobre o qual o filósofo se debruça detidamente -, Sartre mostra que a consciência pode se dirigir para a ação e ser consciente de um objeto sem que ela seja consciente de si mesma; isso não significa que ela seja inconsciente de si, mas consciente de si não-teticamente, ou seja, consciente de si sem por a si mesma como objeto, "[...] e sua maneira de ser consciente de si não-teticamente é transcender-se e perceber-se no mundo como uma qualidade das coisas" (SARTRE, 1939/2010, p. 42 , grifos meus). Dessa maneira, se, por exemplo, durante um jogo de futebol, surge o momento em que devo chutar a bola em direçáo ao gol, não me dou conta de que eu preciso chutar a bola, mas de que a bola precisa ser chutada. $\mathrm{O}$ mesmo vale para a afetividade: se, por exemplo, amo Maria, isso não significa que tenho consciência de mim mesmo como amando Maria, mas que tenho

${ }^{13}$ Identifico e exponho, a seguir, três momentos eidéticos fundamentais do Esboço. 
consciência de seus encantos ${ }^{14}$. A diferença entre essas duas formulações não aparece ao sujeito no plano meramente linguístico, mas, sim, ontológico, porquanto são qualidades existentes que ele detecta. Logo, o móvel dessas situaçôes é uma transformação que se dá não em meu "ser psíquico", mas no mundo - o que prova que, em tais situaçóes, prescinde-se de qualquer recurso à interioridade, e afasta a pressuposição equivocada a respeito da natureza da consciência, segundo o autor, avançada pela psicologia e pela psicanálise.

Esse esclarecimento é necessário para trazer ao centro da discussão a noção de espontaneidade da consciência, fundamental, por sua vez, para sanar definitivamente as dúvidas que ainda venham a pairar sobre o caráter irrefletido e intencional da consciência nas situaçóes de tipo descrito acima. Sartre procura ilustrar essa espontaneidade por meio de uma breve alusão ao sonho e à histeria. Esses fenômenos da consciência atestam que esta se conduz por sua própria espontaneidade. Nesse sentido, podemos dizer que o trabalho onírico e o sintoma histérico se fazem - independentemente de nossa reflexão. Isso significa que a consciência vive essa espontaneidade a tal ponto que náo pode haver qualquer lugar para uma atividade reflexiva. Por conseguinte, admitir, simultaneamente, o caráter espontâneo e reflexivo da consciência redundaria em uma contradição flagrante. Ora, é evidente que o sonho e a histeria, testemunhos dessa espontaneidade, deixam de existir assim que a reflexão aparece: do sonho passase à vigília, da paralisia do membro histérico, ao seu funcionamento corriqueiro. Assim, é impossível à consciência, siderada por sua espontaneidade, que tome a si própria como objeto: se a essência da consciência é transcender-se, " [...] é-lhe impossível, portanto, retirar-se nela para duvidar de que ela esteja fora, no objeto" (SARTRE, 1939/2010, p. 55). É com base nessa elucidação crucial que o autor pode, em seguida, reafirmar a intencionalidade da consciência ao dizer que as "exigências e tensōes" estão no mundo, e não em mim. De fato, as dificuldades e obstáculos que ameaçam minha ação se apresentam como qualidades percebidas, e não como projeçôes de minhas reflexóes. Enfim, a noção de espontaneidade permite a Sartre ao mesmo tempo interditar de uma vez por todas o recurso ao ato reflexivo e retomar o caráter intencional da relaçáo da consciência com o mundo. Por isso, é tão importante ao autor "[...] mostrar

\footnotetext{
${ }^{14}$ Assim, o autor poderá concluir, em $O$ Imaginário, que, se James sustentava que a afetividade se desvaneceria ao se retirarem suas manifestaçóes corporais, Sartre atesta que a afetividade se desvanece ao se ignorar a intencionalidade da emoção: "[...] tentem realizar em vocês [vous] os fenômenos subjetivos do ódio, da indignação sem que esses fenômenos sejam dirigidos para uma pessoa odiosa, para uma ação injusta. Vocês podem tremer, cerrar os punhos, corar de raiva, mas seu estado íntimo será tudo menos indignação, raiva” (SARTRE, 1940/1986, p. 137).
} 
que a consciência espontânea irrefletida constitui uma camada existencial do mundo [...]" (SARTRE, 1939/2010, p. 42, grifos meus).

Ao mesmo tempo, a caracterização da espontaneidade da consciência é o que possibilita, finalmente, entender em que medida a emoção é uma transformação do mundo. Para o autor, a emoção é a instauração de um outro mundo, de caráter mágico, no momento em que algo obsta a minha ação. Isto é, frente à impossibilidade de agir no mundo material (chamado pelo autor de "mundo dos utensílios"), um outro modo de apreensão (saisie) se dá, condicionado por uma mudança súbita de intenção que cria um mundo mágico no qual vigoram conexôes causais e processos diferentes dos que vigem nesse mundo material. Não é mais necessário insistir que essa mudança de intenção se dá no plano irrefletido, mas é preciso frisar o papel central da espontaneidade da consciência nesse processo, pois é ela que apreende a impossibilidade de ação efetiva, ordena uma outra conduta e confere outra qualidade ao objeto (SARTRE, 1939/2010, p. 44). Portanto, a transformação promovida pela emoção se dá graças à espontaneidade da consciência, nesse nível mágico não efetivo, e é nessa medida que deve ser compreendida.

Com isso, Sartre efetua um segundo passo importante para a compreensão de sua teoria, o qual permite, enfim, que o sentido e a finalidade da emoção sejam elucidados. Mesmo quando minha ação é bloqueada pelas dificuldades as quais o mundo material apresenta, ela acaba por se desenvolver de forma mágica, ou seja, num nível "inferior", quiçá mais originário ${ }^{15}$, de conduta, no qual as "superestruturas racionais" (SARTRE, 1939/2010, p. 58) e o determinismo não mais legislam. Isso significa que a finalidade dessa ação se realiza de alguma forma, se bem que não da maneira como se pressupunha de início - daí o elogio feito à noção de "conduta de fracasso" de Janet e ao conceito de "evasão" dos gestaltistas. Sartre se dedica a ilustrar a validade desse princípio funcional por meio de exames notáveis do medo, da tristeza e da alegria, em suas formas "ativa" e "passiva"16. Essas análises são suficientes, a despeito da excessiva preocupação de Sartre com o fato de serem apenas exemplos, e o problema de que parte o autor - a ausência da dimensão do sentido e da finalidade nas teorias psicológicas - é resolvido: o papel funcional da emoção está ilustrado a contento.

15 Cf. TOMÈS, 2010, p. CVI.

${ }^{16} \mathrm{O}$ que, mais uma vez, parece indicar o uso de distinçōes presentes nos tratados de Dumas. 
Entretanto, se a atividade espontânea da consciência é central em todo esse processo, como vimos, é forçoso, então, à luz de toda a exposição sobre a teoria de James, perguntar-se pelo papel do corpo na teoria sartreana da emoção. Afinal, é justamente nesse momento, após salientar a centralidade da espontaneidade da consciência, que Sartre introduz, de forma abrupta, senão apressada, a questão do corpo: "Numa palavra, na emoção é o corpo que, dirigido pela consciência, muda suas relaçóes com o mundo para que o mundo mude suas qualidades" (SARTRE, 1939/2010, p. 44, grifos meus). Como se apenas estivesse retomando uma discussão, embora esteja enunciando algo novo de fato, o autor introduz esse elemento fundamental, o corpo, em sua teoria, e suscita mais dúvidas que esclarecimentos. Mesmo após essa introdução repentina, o autor não se detém sobre a questão, e volta a esse ponto somente após ilustrar o papel funcional da emoção. Os esclarecimentos prestados quanto a esse papel, todavia, deixam entrever a função do corpo em passagens como a que se refere ao medo passivo, no qual a conduta fisiológica "[...] representa a realização brusca das condiçóes corporais que acompanham comumente a passagem da vigília ao sono” (SARTRE, 1939/2010, p. 46, grifo meu); ou na passagem que conclui tais esclarecimentos, na qual ele atesta que as emoçóes examinadas constituem "[...] um mundo mágico ao utilizar nosso corpo como meio de encantamento" (SARTRE, 1939/2010, p. 50, grifos meus). Ainda que o autor passe a examinar mais detidamente o papel do corpo na emoção logo após esses esclarecimentos, já é possível entrever o destaque dado à espontaneidade da consciência em proveito da atividade corporal.

O exame mais detido dessa atividade, realizado logo em seguida, atesta que o corpo é hylét7 para a consciência emocionada. Trata-se, como efeito, do momento eidético fundamental do texto, dedicado a verificar a natureza da emoção afinal. $\mathrm{O}$ autor assinala que as manifestações somáticas "[...] representam o sério da emoção, são fenômenos de crença” (SARTRE, 1939/2010, p. 52), pois a verdadeira emoção é acompanhada de crença, de padecimento e, para fazer uso de termo que é caro ao autor, de comoção (bouleversement). Sem esses elementos, a emoção é falsa, porque é produto de uma demanda do outro - de uma "exigência", de uma "realidade parasitária" (SARTRE, 1939/2010, p. 52) -, sendo conduta vazia, pura forma. É necessário que "[...] o quadro formal da conduta seja preenchido por algo opaco e pesado que lhe sirva de matéria" (SARTRE, 1939/2010, p. 52, grifos meus), papel

\footnotetext{
${ }^{17}$ Porquanto os problemas que gravitam em torno da hylé não são evidenciados e discutidos no Esboço, diferentemente do que ocorre em $O$ Imaginário e $O$ Ser e o nada, pode-se, no Esboço, entender a hylé simplesmente como matéria que é animada pela consciência emocionada.
} 
que é desempenhado pela perturbação fisiológica. Se é verdade que esta pode ter uma existência independente da conduta, a conduta, não obstante, "[...] constitui a forma e a significação da comoção" (SARTRE, 1939/2010, p. 53). Assim, da mesma maneira que forma e matéria se unem numa síntese, conduta e manifestaçôes corporais se juntam na unidade sintética que é a emoção. Nesses termos, o corpo possui função hylética na emoção: ele é matéria para a consciência emocionada, meio pelo qual a emoção revela sua veracidade, índice da crença que conduz o sujeito emocionado.

Assim, o terceiro passo fundamental para a compreensão da teoria sartreana foi dado, porquanto o que vem em seguida visa apenas a precisar ou simplesmente reforçar alguns pontos dessa teoria - o caráter cativo da consciência emocionada, sua duração (questáo necessária para a explicação das emoçôes finas) e suas diferentes maneiras de ser no mundo. Sartre procura igualmente refinar o caráter do corpo - o que nos é do maior interesse. $\mathrm{O}$ autor revela que o corpo possui uma dupla função: ele, por um lado, é “[...] um objeto no mundo e, por outro, o vivido imediato da consciência" (p. 53). Isto é, medida em que o corpo pode ser tomado como "corpo-coisa" ou "corpo-biológico" (SARTRE, 1939/2010, p. 54), ele é apenas mais um dos utensílios presentes no mundo material; mas ele também é índice da mudança na espontaneidade da consciência verificada na emoção. Nesse caso, "[...] a consciência muda de corpo, ou se preferirem, o corpo - na qualidade de ponto de vista sobre universo imediatamente inerente à consciência - coloca-se ao nível das condutas" (SARTRE, 1939/2010, p. 53, grifos meus). Destarte, o corpo emocionado implica um mundo transformado e a apreensáo de um mundo mágico pela consciência. Todos esses são, sem dúvida, detalhamentos importantes, mas que dependem do passo fundamental responsável por evidenciar que a emoçáo é uniáo sintética da conduta e das perturbaçóes fisiológicas sob o signo da magia e da crença - tal é a essência do fenômeno emotivo.

Sendo assim, visto que isso doravante nos autoriza a avaliar a empreitada teórica de Sartre, já é possível atentar para o estatuto problemático do corpo, nessa teoria.

Em primeiro lugar, deve-se notar que se, por um lado, Sartre realmente agrega em sua eidética a importante função do corpo de conferir à emoção seu caráter de padecimento, é apenas na condição de matéria para a intenção da consciência, por outro lado, que o corpo adquire foros de cidadania nessa teoria. Nesse sentido, o corpo é passivo diante da espontaneidade criadora da consciência. Conquanto reitere o aspecto sintético da emoção - “[...] 
deparamo-nos aqui claramente com uma forma sintética: para crer, é preciso estar comovido [bouleversé]" (SARTRE, 1939/2010, p. 53) -, o filósofo francês distingue a passividade do corpo da atividade da consciência sempre que decide destacar o papel dos componentes dessa síntese. Basta que se preste atenção, sobretudo, nos verbos aplicados pelo autor para se referir à consciência, os quais estão, na maioria das vezes, na voz ativa ou reflexiva. Desse modo, dizse que a consciência "apreende", "ordena", "confere", "crê", "transforma seu corpo" 53) "arrasta [entraîne]" ao mundo mágico, "[...] precipita-se no mundo mágico da emoção" (SARTRE, 1939/2010, pp. 53 e 59), "interessa-se" por ele, "degrada-se", "emociona-se", "transcende-se" - ao passo que o corpo é "dirigido pela consciência", serve como meio de encantamento, resultado da "vivência imediata $d a$ consciência". Nesses termos, o corpo é continente da espontaneidade da consciência: daí sua passividade ${ }^{18}$.

Se isso é verdade, então se cria, em segundo lugar, um problema, já que a passividade do corpo é um predicado da teoria intelectualista, a qual, como sabemos, Sartre busca superar. Como mostrei, o autor considera que, em tal teoria, os distúrbios fisiológicos são consequência de um "estado íntimo" tomado como antecedente. A fim de provar que essa consideração não pode ser verdadeira, o filósofo francês procura não apenas recuperar a insistência jamesiana no caráter padecido da emoção como também demonstrar que o próprio conceito de "estado íntimo" é equivocado, porquanto pressupóe o intermédio de uma atividade anímica reflexiva na causação da emoção. $\mathrm{O}$ autor inclusive questiona a noção mesma de causação da emoção, se se admite que ela é do tipo determinista; nesse caso, a emoção seria um "fato" ou mero "acidente", extrínseco, portanto, à "realidade humana”. Ao contrário, Sartre demonstra que a emoção "[...] não é desordem passageira do organismo e do espírito que viria a perturbar de fora a vida psíquica” (SARTRE, 1939/2010, p. 62), mas “[...] um modo de existência da consciência, uma das maneiras como ela compreende (no sentido heideggeriano de Verstehen) seu 'Ser-no-Mundo'" (SARTRE, 1939/2010, p. 62). Vê-se que, a despeito de todas essas retificaçôes promovidas pelo autor, é, ainda assim, a consciência que rege a emoção. Por mais que essas retificaçóes o distanciem do intelectualismo clássico, é na medida em que o autor pressupóe, do começo ao fim, o primado da consciência no fenômeno emocional que sua posição teórica guarda semelhanças com a intelectualista.

\footnotetext{
${ }^{18}$ Bem entendido, a passividade a que me refiro diz respeito ao corpo emocionado, e nấo ao corpoobjeto. Este é passivo sem dúvida, posto que sujeito a efeitos de outros seres e intempéries, por exemplo. Considero que o problema reside em atribuir passividade ao corpo emocionado, mesmo que se conceda a esse um papel capital numa estrutura sintética que, em si, é ativa.
} 
Ora, isso não deveria causar surpresa, posto que Sartre, desde o início de seu texto, supóe que a emoção tem um sentido que pode ser compreendido. Como efeito, esse termo, que o autor faz questão de destacar e remeter ao original alemão (verstehen), marca uma posição teórica num debate que se desenvolveu na Alemanha no final do século XIX. Conhecido como "querela dos métodos (Methodenstreit)", essa disputa colocou em confronto duas orientações teóricas distintas: as ciências naturais (Naturwissenshaften), que procuravam explicar (erklären) os fenômenos, e as ciências do espírito (Gesteswissenschaften), as quais buscavam compreender (verstehen) os fenômenos; isto é, enquanto as primeiras tentavam remontar às causas dos fenômenos, as últimas almejavam lhes devolver o sentido. Como indica Tomès (2010), Sartre calca-se sobre os preceitos das ciências do espírito, e essa busca pela compreensão do sentido é um princípio que o autor de $O$ Ser e o nada "[...] conservará sempre [...]" (TOMÈS, 2010, p. XXXIII). À luz desses esclarecimentos, as bases do antinaturalismo ou antimecanicismo de Sartre são mais bem compreendidas. Ademais, tais esclarecimentos permitem atinar com a falta de lugar para a espontaneidade do corpo numa teoria com essas feiçôes. Se ao corpo é vedado significar, tarefa, no entanto, primordial e a qual cabe apenas à consciência, desde logo se anuncia que ele é um instrumento da consciência, o que lhe retira toda a espontaneidade. Se a plêiade de reaçóes fisiológicas deve fazer parte de uma estrutura inteligível e organizada, a voluntariedade somática é um escândalo. Vê-se que na compreensão sartreana da emoção não há lugar para a espontaneidade do corpo.

Nesse sentido, alinho-me às críticas pioneiras de P. Ricoeur, para quem a teoria sartreana da emoção, fundamentalmente,

[...] tende a eliminar a iniciativa do corpo [...] em proveito unicamente da espontaneidade da consciência. O corpo é um pouco mais que um simples órgão para uma consciência que desce [śabaisse] ao nível mágico. (RICOEUR, 1950/1967, p. 258).

Ricoeur também considera insatisfatório, portanto, o estatuto do corpo na teoria de Sartre, mostrando que este náo se dá conta de que "[...] a emoção é uma desordem nascente", na qual "[...] não há inteligibilidade intrínseca” (RICOEUR, 1950/1967, pp. 256 e 257 - grifos meus). O desiderato de uma inteligibilidade completa da emoção impede que Sartre enxergue a negatividade do corpo, do qual emerge uma desordem bruta e opaca que representa um desafio para a compreensão. Essa dimensão é 
completamente ignorada na teoria sartreana; Sartre suspeita até da existência de tal dimensão, porquanto supóe que as manifestaçóes corporais recebem sua inteligibilidade pela consciência desde o início. Embora não se trate de postular uma causalidade ostensiva da atividade anímica sobre a somática, trata-se de admitir uma antecedência da espontaneidade da consciência relativamente ao corpo. É em função do império velado dessa espontaneidade sobre o corpo que Ricoeur denomina a posição de Sartre de "[...] idealismo implícito [cachée]" (RICOEUR, 1950/1967, 259).

Ainda que outros autores igualmente detectem alguns desses problemas atinentes à relação entre corpo e consciência na eidética sartreana da emoção ${ }^{19}$, creio que a exposição realizada no presente artigo permita indicar, sobretudo, que a solução algo idealista de Sartre se deve às exigências internas ao próprio texto do Esboço. Apesar dos esforços do autor e do grande distanciamento que ele de fato conseguiu com relação ao intelectualismo clássico, o fantasma do intelectualismo ainda ronda o texto sartreano.

Assim, a exposição que realizei no presente trabalho visou a revelar algumas dificuldades que cercam a definição do estatuto do corpo no Esboço. Mais precisamente, procurei mostrar de que maneira o imperativo da significação e, consequentemente, o primado da consciência levaram Sartre a conceber o papel do corpo na emoção, de forma problemática.

\section{Agradecimentos}

Agradeço o estímulo decisivo e a assistência do professor Marcus Sacrini, do Departamento de Filosofia da Faculdade de Filosofia, Letras e Ciências Humanas da Universidade de São Paulo (FFLCH-USP), em diferentes etapas de elaboração do presente artigo.

\footnotetext{
${ }^{19}$ Por exemplo, Cabestan (2004, p. 94) acena para tais problemas, ao afirmar que "[...] se vê facilmente, independentemente da relevância ou da exatidão da descrição sartreana da emoção, que ela não descreve precisamente o modo como o corpo toma parte nesse tipo de comportamento [behavior]". Já Colombetti (2011, p. 301, grifos meus) reconhece os senōes da primazia da consciência na teoria sartreana, embora o foco da autora náo seja o exame detido dessa teoria e tampouco sua crítica: "[...] por causa do modo como encara a consciência, Sartre não pode dizer que o corpo perturbado [upset] na emoção, por meio do qual a consciência transforma o mundo, experimenta a si mesmo como perturbado [...] Na emoção, o corpo é usado pela consciência para transformar o mundo; a consciência até mesmo se degrada nesse processo, mas o corpo nunca experimenta a si mesmo".
} 
FERRETTI, Marcelo Galletti. The status of the body in Jean-Paul Sartre's Esquisse d'une théorie des émotions. Trans/Form/Ação, Marília, v. 36, n. 3, p. 129-154. Set./Dez., 2013.

\begin{abstract}
In this paper I intend to reveal some difficulties surrounding the definition of the status of the body in Jean-Paul Sartre's Esquisse d'une théorie des émotions (Sketch for a theory of the emotions), published in 1939. Such difficulties are fundamentally due to the primacy of consciousness in Sartre's eidetic of emotion, which subordinates the activity of the body to the spontaneity of consciousness. This is a theoretical position that bears resemblance to intellectualism, something which is criticized by Sartre from outset of the work in question. With the purpose of treating these issues, I attempt to explain Sartre's eidetic of emotion by emphasizing the problematic status of the body in this eidetic. First, however, it is necessary to examine Sartre's strictures against psychological theories of emotion, especially that of William James, as well as to examine some of James' main theses on emotion.
\end{abstract}

KEY WORDS: Sartre. Emotion. Body. Consciousness. Psychology. Phenomenology.

\title{
REFERÊNCIAS
}

BAUGH, B. Sartre and James on the role of the body in emotion. Dialogue, Canadá, vol. 29, n. 3, p. 357-373, 1990.

CABESTAN, P. What is to move oneself emotionally? Emotion and affectivity according to Jean-Paul Sartre. Tradução de Kirk M. Besmer. Phenomenology and the Cognitive Sciences, Holanda, vol. 3, p. 81-96, 2004.

CANGUilHEM, G. O normal e o patológico. Tradução de Maria Thereza Redig de Carvalho Barrocas. Rio de Janeiro: Forense-Universitária, 1978.

CARROY, J.; OHAYON, A.; PLAS, R. Histoire de la psychologie en France. XIX'-XX siècles. Paris: La Découverte, 2006.

COLOMBETTI, G. Varieties of pre-reflexive self-awareness: foreground and background bodily feelings in emotion experience. Inquiry, Inglaterra, vol. 54, n. 3, p. 293-313, 2011.

COOREBYTER, V. d. Esquisse d'une théorie des émotions. In: NOUDELMANN, F; PHILIPPE, G. (Org.). Dictionnaire Sartre. Paris: Honoré Champion, 2004, p. 163-165.

DIXON, T. From passions to emotions. The creation of a secular psychological category. Cambridge: Cambridge University Press, 2006.

DUMAS, G. (Org.). Traité de psychologie. Paris: Librairie Félix Alcan, 1923. 2 v. . Nouveau traité de psychologie. Paris: Librairie Félix Alcan, 1932. 5 v. 
FOUCAULT, M. A psicologia de 1850 a 1950. In: FOUCAULT, M. Problematização do sujeito: Psicologia, Psiquiatria e Psicanálise. Rio de Janeiro: Forense Universitária, 1999, p. 122-139. (Coleção Ditos \& Escritos, v. 1)

JAMES, W. (1890). The Principles of Psychology. Cambridge, MA: Harvard University Press, 1983.

LALANDE, A. Vocabulaire technique et critique de la philosophie. 11. ed. Paris: Presses universitaries de France, 1972.

MOUTINHO, L. D. S. Sartre: psicologia e fenomenologia. São Paulo: Brasiliense, 1995.

RIBOT, T-A. La psychologie des sentiments. Paris: Félix Alcan, 1896. Disponível em: http:// gallica.bnf.fr/ark:/12148/bpt6k654204/ . Acesso em: 13 nov. 2011.

RICHARDS, R. J. Darwin and the emergence of evolutionary theories of mind and behavior. Chicago e Londres: University of Chicago Press, 1989.

RICOUER, P. (1950). Philosophie de la volonté. Tome I: Le volontaire et l'involontaire. Paris: Aubier, 1967.

SARTRE, J-P. (1937) La Transcendance de l'ego: Esquisse d'une description phénomenologique. Paris: Librairie Philosophique J. Vrin, 1966. . (1939). Esquisse d'une théorie des émotions. Paris: Hermann, 2010.

. (1940). L’imaginaire: psychologie phénoménologique de l’imagination. Paris: Gallimard, 1986.

TOMÈS, A. Préface à L'Esquisse d'une théorie des émotions de Jean-Paul Sartre. In: SARTRE, J-P. Esquisse d'une théorie des émotions. Paris: Hermann, 2010, p. IX-CXIII.

VAUDAY, P. Georges Dumas. In: NOUDELMANN, F.; PHILIPPE, G. (Org.). Dictionnaire Sartre. Paris: Honoré Champion, 2004.

Recebido em: 14.09.2012

Aceito em: 19.04.2013 
FERRETTI, M. G. 